\title{
Production of porous ceramic material using different sources of alumina and calcia
}

\author{
Ivone Regina de Oliveira ${ }^{1}$, Vitoria Marques Cesar Leite ${ }^{1}$, \\ Milene Paula Vargas Porto Lima ${ }^{1}$, Rafael Salomão ${ }^{2}$
}

\author{
${ }^{1}$ Institute for Research and Development, University of Vale do Paraiba, São José dos Campos, SP \\ e-mail: ivonero@univap.br \\ ${ }^{2}$ Materials Engieering Department, São Carlos School of Engineering, University of São Paulo, São Carlos, SP \\ e-mail: rsalomao@sc.usp.br
}

\begin{abstract}
Numerous papers and publications report the use of microporous calcium hexaluminate $\left(\mathrm{CaO} 6 \mathrm{Al}_{2} \mathrm{O}_{3} ; \mathrm{CA}_{6}\right)$ as a key raw material for high temperature insulating materials. This material has unique properties with respect to chemical purity and mineral composition. Another important property of $\mathrm{CA}_{6}$ is its structure, which consists of platelet-shaped crystals that interlock. The free distance between the crystals defines the microporous structure. The low density in combination with the micropores hampers heat transfer by radiation at temperatures exceeding $1000{ }^{\circ} \mathrm{C}$ and results in a low thermal conductivity. Given the advantages presented by this material, it is necessary to understand the formation mechanism of $\mathrm{CA}_{6}$ grains in order to better develop the potential applications of this material. $\mathrm{CA}_{6}$ can be fabricated using organic binders to consolidate the $\mathrm{Al}_{2} \mathrm{O}_{3}-\mathrm{CaCO}_{3}$ powder mixture and to provide green strength so that a green body can be formed and retains the desired shape before heating. However, these organic binders must be completely thermally decomposed so that they do not remain in the sintered body as carbon or ash. Moreover, the use of organic binders releases large volumes of gases such as carbon dioxide from the green body during heating. Therefore, an eco-friendly ceramic fabrication process has been developed that employs an inorganic binder (hydraulic alumina). The aim of the present work was to study the synthesis of porous calcium-hexaluminate ceramics using calcined alumina or hydraulic alumina combined with different sources of calcia $\left(\mathrm{CaCO}_{3}\right.$ and $\left.\mathrm{Ca}(\mathrm{OH})_{2}\right)$ at different temperatures. The materials produced were characterized by X-ray diffraction, scanning electron microscopy, apparent porosity and mercury intrusion porosimetry. The materials produced by hydraulic alumina presented higher porosity and larger pores compared to those produced from calcined alumina.
\end{abstract}

Keywords: Calcium hexaluminate, synthesis, inorganic binder, properties.

\section{INTRODUCTION}

Ceramic fiber-based materials are widely employed as thermal insulators for high temperature applications (above $1200^{\circ} \mathrm{C}$ ) due to their low thermal conductivity and thermal shock resistance. Recently, due to their potential for causing lung diseases and allergies, efforts have been made to replace these materials by nonfiber containing alternatives [1-4]. The microporous monolithic ceramics are the most important candidates [5]. Differently from the fiber-based boards, in porous monolithics, the ceramics matrixes comprise sintered particles surrounding micro-to-macro porous. Due to this, this class of materials presents low thermal conductivity and reduces the generation of hazardous dust during installation and use. Recent studies report porous calcium hexaluminate structures as suitable candidates for this application [ $\underline{1}-\underline{5}$ ].

Calcium hexaluminate $\left(\mathrm{CaAl}_{12} \mathrm{O}_{19}, \mathrm{CaO} .6 \mathrm{Al}_{2} \mathrm{O}_{3}\right.$, or simply $\left.\mathrm{CA}_{6}\right)$, also known as hibonite, is an alumina-rich intermediate compound of the $\mathrm{CaO}-\mathrm{Al}_{2} \mathrm{O}_{3}$ system, with high thermal stability and refractoriness (melting point of $1830^{\circ} \mathrm{C}$ ) [ $\left.\underline{1}, \underline{4}-\underline{7}\right]$. It is formed according with the general expression:

$$
6 \mathrm{Al}_{2} \mathrm{O}_{3}+\mathrm{CaO} \rightarrow \mathrm{CaAl}_{12} \mathrm{O}_{19}
$$


Considering its use for thermal insulation, $\mathrm{CA}_{6}$ has three important and simultaneous advantages over other systems: 1) it presents intrinsic resistance for densification, therefore, preventing densification of the structure during use at high temperatures [8]; 2) it allows the generation of structures with large volume of microporous and homogeneous microstructure [4-]ㄱ; and 3) due to its plate-like crystalline habit provides high fracture energy and thermal shock resistance [ $\underline{3}-\underline{5}]$.

The difficulties in sintering and densification of $\mathrm{CA}_{6}$ were described in studies focused in producing dense optical devices and were attributed to multiple aspects. In sintering pre-formed $\mathrm{CA}_{6}$, the densification difficulties are associated with the plate-like shape of its particles and with the large average crystal size and their high stability. Furthermore, because $\mathrm{CA}_{6}$ is a solid solution with broad range of composition, the absence of second phases at the grain boundaries easies grain growth instead of densification as main sintering mechanism. For in situ generation by solid-state reaction (between precursors such as $\mathrm{CaO}$ and $\mathrm{Al}_{2} \mathrm{O}_{3}$ ), other aspects also impede sintering. $\mathrm{CA}_{6}$ formation is a double-diffusion mechanism, where $\mathrm{Ca}^{2+}, \mathrm{Al}^{3+}$, and $\mathrm{O}^{2-}$ ions are mutually exchange amongst the particles. Because there are significant differences between the diffusion rates of $\mathrm{Ca}^{2+}$ in $\mathrm{Al}_{2} \mathrm{O}_{3}$ and $\mathrm{Al}^{3+}$ in $\mathrm{CaO}$, the overall kinetics of the reaction is slow and several intermediate compounds can be formed and decomposed before reaching the desired composition. In addition, due to the density mismatch of reactants $\left(\rho \mathrm{Al}_{2} \mathrm{O}_{3}=4 \mathrm{~g} \cdot \mathrm{cm}^{-3}\right)$ with $\left(\rho \mathrm{CaO}=3.5 \mathrm{~g} . \mathrm{cm}^{-3}\right)$ and $\mathrm{CA}_{6}(\rho=3.2$ g. $\left.\mathrm{cm}^{-3}\right)$, its formation is followed by a volumetric expansion that can keep particles apart, preventing densification.

Regarding the thermal shock behavior, insulating materials experience severe stresses during use caused by sudden temperature variations. Usually, these stresses are high enough to generate and propagate catastrophic cracks all over the structure. In $\mathrm{CA}_{6}$ systems, on the other hand, crack propagation is impeded by the microporous and tortuous structure. Due to this, these materials present high thermal shock resistance despite their low density [ $\underline{3}, \underline{4}]$ allowing the production of very complex and large-sized components [4]. Even under severe conditions, for example exposure to harsh thermal shock conditions or alkali attack, service life has by far exceeded initial expectations [3,7]. This interesting combination of high refractoriness and thermomechanical performance allows $\mathrm{CA}_{6}$ to be used in many industrial applications such as refractories for steel and glass making, non-ferrous foundry and petrochemical unities $[3, \underline{7}, \underline{9}]$.

The pores formation in $\mathrm{CA}_{6}$ structures can be carried out by two main routes. The first is the compacting and sintering of pre-formed $\mathrm{CA}_{6}$ generating the so-called light-weight aggregates. Some variations that include the introduction of organic porogenic (such as starch) or foamed suspensions (using surfactants) are also possible [8]. Because of the high energy consumption of the pre-formed material, alternative routes have been developed, such as the combination of $\mathrm{Al}_{2} \mathrm{O}_{3}$ and $\mathrm{CaCO}_{3}$ precursors $[\underline{6}, \underline{8}]$. In these cases, the pore generation occurs during the decomposition reactions and can be partially preserved during sintering. Despite the high porosity levels achieved, the use of carbonated precursors inevitably produces $\mathrm{CO}_{2}$ as by-product.

Searching for a more environmentally-friend system, this study aimed to produce porous $\mathrm{CA}_{6}$ structures combining alternative $\mathrm{Al}_{2} \mathrm{O}_{3}-\mathrm{CaO}$ sources: calcined $\mathrm{Al}_{2} \mathrm{O}_{3}\left(\alpha-\mathrm{Al}_{2} \mathrm{O}_{3}\right)$ and hydraulic $\mathrm{Al}_{2} \mathrm{O}_{3}\left(\rho-\mathrm{Al}_{2} \mathrm{O}_{3}\right)$ and $\mathrm{CaO}$ (decomposed $\mathrm{CaCO}_{3}$ ) and $\mathrm{Ca}(\mathrm{OH})_{2}$, respectively. After sintering at different temperatures, physical and morphological characterizations were carried out. The results attained were related to the properties and characteristics of the precursor raw materials.

\section{MATERIALS AND METHODS}

Calcined alumina (CA, $\alpha-\mathrm{Al}_{2} \mathrm{O}_{3}, \mathrm{~A} 1000 \mathrm{SG}$, Almatis, USA), hydraulic alumina (HA, $\rho-\mathrm{Al}_{2} \mathrm{O}_{3}$, Alphabond 300, Almatis, USA), calcium carbonate $\left(\mathrm{CaCO}_{3}\right.$, Vetec, Brazil), and calcium hydroxide $\left(\mathrm{Ca}(\mathrm{OH})_{2}, \mathrm{Synth}\right.$, Brazil) were used as reactants. The morphology of particles was analysed by scanning electron microscopy (EVO MA10; Zeiss) as showing in Figure 1. Others characteristics of the materials are presented in Table 1. Raw materials were mixed accordingly to their chemical composition (Table 2) to produce calcium hexaluminate following the general expressions:

$$
\begin{aligned}
& \rho-\mathrm{Al}_{2} \mathrm{O}_{3} \rightarrow \alpha-\mathrm{Al}_{2} \mathrm{O}_{3} \\
& 6 \alpha-\mathrm{Al}_{2} \mathrm{O}_{3}+\mathrm{CaCO}_{3} \rightarrow 6 \alpha-\mathrm{Al}_{2} \mathrm{O}_{3}+\mathrm{CaO}+\mathrm{CO}_{2} \rightarrow \mathrm{CaAl}_{12} \mathrm{O}_{19} \\
& 6 \alpha-\mathrm{Al}_{2} \mathrm{O}_{3}+\mathrm{CaO} \rightarrow \mathrm{CaAl}_{12} \mathrm{O}_{19} \\
& 6 \alpha-\mathrm{Al}_{2} \mathrm{O}_{3}+\mathrm{Ca}(\mathrm{OH})_{2} \rightarrow 6 \alpha-\mathrm{Al}_{2} \mathrm{O}_{3}+\mathrm{CaO}+\mathrm{H}_{2} \mathrm{O} \rightarrow \mathrm{CaAl}_{12} \mathrm{O}_{19}
\end{aligned}
$$




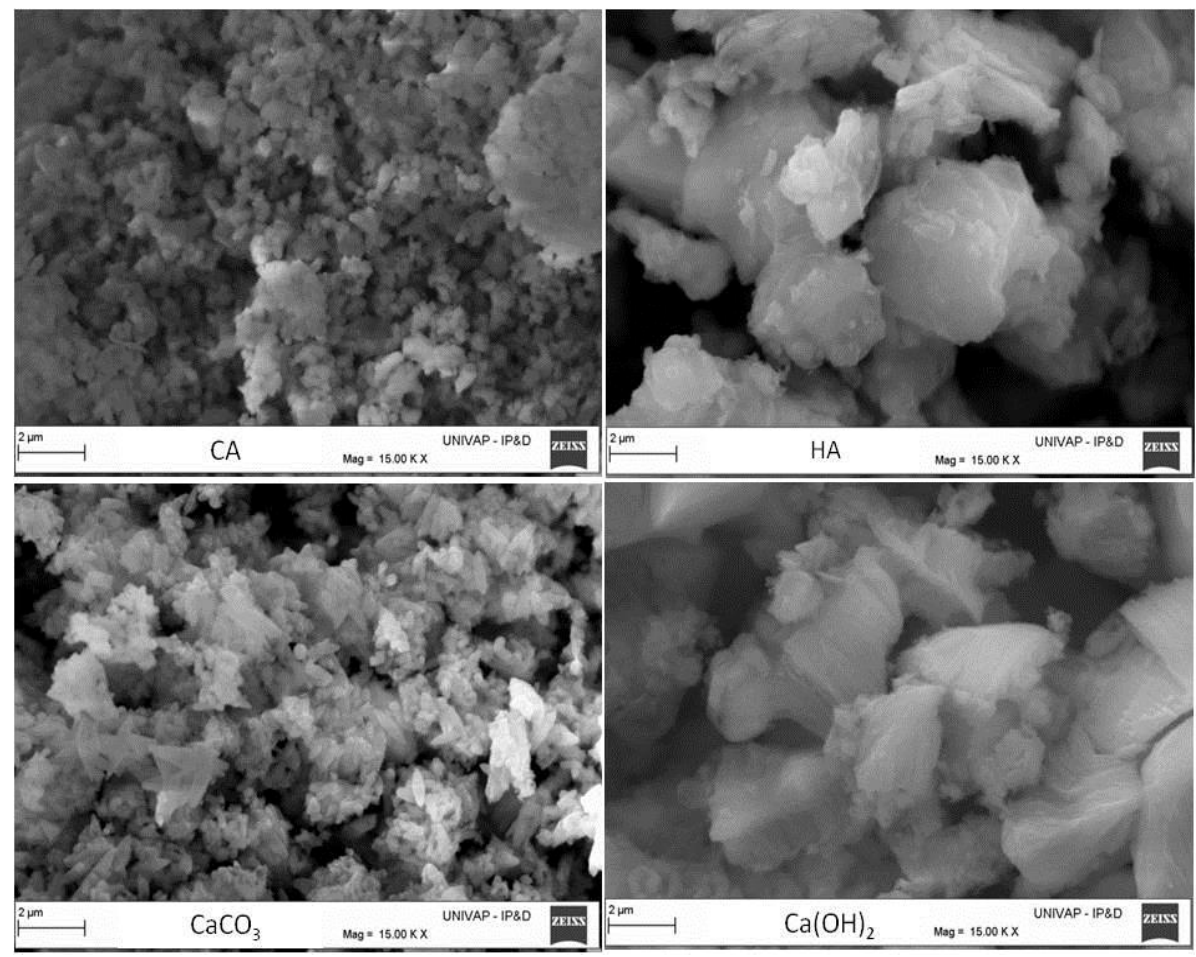

Figure 1: Scanning electron microscopy for as-received particles calcined alumina (CA), hydraulic alumina (HA), $\mathrm{CaCO}_{3}$ and $\mathrm{Ca}(\mathrm{OH})_{2}$.

Table 1: Characteristics of the raw materials

\begin{tabular}{|c|c|c|c|c|}
\hline & $\begin{array}{c}\text { Calcined } \\
\text { alumina } \\
\left(\mathrm{CA}, \alpha-\mathrm{Al}_{2} \mathrm{O}_{3}\right) \\
\end{array}$ & $\begin{array}{c}\text { Hydratable } \\
\text { alumina } \\
\left(\mathrm{HA}, \rho-\mathrm{Al}_{2} \mathrm{O}_{3}\right) \\
\end{array}$ & $\begin{array}{l}\text { Calcium carbonate } \\
\qquad\left(\mathrm{CaCO}_{3}\right)\end{array}$ & $\begin{array}{l}\text { Calcium hydroxide } \\
\quad\left(\mathrm{Ca}(\mathrm{OH})_{2}\right)\end{array}$ \\
\hline $\begin{array}{l}\text { Solid densi- } \\
\text { ty }\left(\mathrm{g} \cdot \mathrm{cm}^{-3}\right)\end{array}$ & 3.95 & 2.72 & 2.83 & 2.21 \\
\hline $\begin{array}{c}\text { Specific } \\
\text { surface area } \\
\left(\mathrm{m}^{2} \cdot \mathrm{g}^{-1}\right)\end{array}$ & 7.0 & 95 & - & - \\
\hline $\begin{array}{c}\text { Particle size } \\
\left(\mathrm{D}_{50} / \mathrm{D}_{90}\right. \\
\mu \mathrm{m})\end{array}$ & $0.5 / 1.2$ & $10 / 23$ & $2.2 / 3.8$ & $6.5 / 13$ \\
\hline $\begin{array}{l}\text { Composition } \\
\text { (wt.\%) }\end{array}$ & $\begin{array}{c}\mathrm{Al}_{2} \mathrm{O}_{3}: 99.8 \\
\mathrm{Na}_{2} \mathrm{O}: 0.08 \\
\mathrm{Fe}_{2} \mathrm{O}_{3}: 0.02 \\
\mathrm{SiO}_{2}: 0.03 \\
\mathrm{CaO}: 0.02 \\
\mathrm{MgO}: 0.07\end{array}$ & $\begin{array}{c}\mathrm{Al}_{2} \mathrm{O}_{3}: 99.4 \\
\mathrm{Na}_{2} \mathrm{O}: 0.5 ; \\
\mathrm{Fe}_{2} \mathrm{O}_{3}: 0.02 \\
\mathrm{SiO}_{2}: 0.03 ; \\
\mathrm{CaO}: 0.02 ; \\
\mathrm{MgO}: 0.07\end{array}$ & $\begin{array}{c}\mathrm{CaCO}_{3}: 99.0 ; \mathrm{Sr}: \\
0.1 ; \mathrm{Na}_{0} 0.1 ; \mathrm{SO}_{4}: \\
0.01 ; \\
\mathrm{K}: 0.01 ; \\
\mathrm{Mg}: 0.02 ; \mathrm{Fe}: \\
0.003 ; \mathrm{NH}_{4}: 0.003 ; \\
\mathrm{Cl}: 0.001 ; \mathrm{Ba}: \\
0.005 ; \mathrm{F}: 0.0015 \\
\end{array}$ & $\begin{array}{c}\mathrm{Ca}(\mathrm{OH})_{2}: 95.0 ; \mathrm{CO}_{3}: \\
\text { 3.0; } \mathrm{Cl}: 0.03 ; \mathrm{SO}_{4}: \\
0.1 ; \mathrm{Fe}: 0.05\end{array}$ \\
\hline
\end{tabular}

The different mixtures $\left(\mathrm{CA}-\mathrm{CaCO}_{3}, \mathrm{CA}-\mathrm{Ca}(\mathrm{OH})_{2}, \mathrm{HA}-\mathrm{CaCO}_{3}\right.$, and $\left.\mathrm{HA}-\mathrm{Ca}(\mathrm{OH})_{2}\right)$ were initially homogenized in a ball-mill for 5 hours $(6 \mathrm{~mm}$ corundum spheres were used as milling agent in a 5:1 ratio; no fluid or additives were added to this system) and then uniaxially pressed as cylinders of $20 \mathrm{~mm}$ diameter by 6 $\mathrm{mm}$ height. Sintering was performed at 1550,1600 , and $1650^{\circ} \mathrm{C}$ for $2 \mathrm{~h}$ (heating and cooling rate of $5^{\circ} \mathrm{C} \cdot \mathrm{min}^{-}$ ${ }^{1}$ ) using an oven (Lindberg Blue, U.S.A.). 
Table 2: Evaluated conditions for the production of calcium hexaluminate

\begin{tabular}{c|c|c|c}
\hline ALUMINA SOURCE & CALCIUM SOURCE & PROPORTIONS (wt\%) & SINTERING TEMPERATURE $\left({ }^{\circ} \mathbf{C}\right)$ \\
\hline $\mathrm{CA}$ & $\mathrm{CaCO}_{3}$ & $85.9: 14.1$ & 1550,1600 \\
& $\mathrm{Ca}(\mathrm{OH})_{2}$ & $89.0: 11.0$ & 1550,1600 \\
\hline $\mathrm{HA}$ & $\mathrm{CaCO}$ & $88.0: 12.0$ & $1550,1600,1650$ \\
& $\mathrm{Ca}(\mathrm{OH})_{2}$ & $90.5: 9.5$ & $1550,1600,1650$ \\
\hline
\end{tabular}

The apparent porosity level of the sintered samples was measured by immersion tests using Archimedes' principle, using water as immersion fluid. This principle states that an immersed body is buoyed up by a force equal to the weight of the displaced fluid. The buoyant force is measured by the difference (expressed in grams) between the weight of the body in air and when submerged in water [10]. The samples were initially weighed dried $\left(\mathrm{W}_{\mathrm{d}}, \mathrm{g}\right)$. After 1 hour of immersion in water under vacuum atmosphere, samples were weighed inside the immersion liquid $\left(\mathrm{W}_{\mathrm{i}}, \mathrm{g}\right)$. Next, the excess liquid was removed with a humid blanket and the samples were weight again $\left(\mathrm{W}_{\mathrm{h}}, \mathrm{g}\right)$. The apparent porosity (AP, \%) was calculated considering the mass of liquid retained in its open pores:

$$
\mathrm{AP}=100 \% \times\left[\left(\mathrm{W}_{\mathrm{h}}-\mathrm{W}_{\mathrm{d}}\right) /\left(\mathrm{W}_{\mathrm{h}}-\mathrm{W}_{\mathrm{i}}\right)\right]
$$

Pore size distribution of samples was determined by mercury intrusion porosimetry (Autopore IV 9500, Micromeritics). In this technique, a non-wetting liquid (mercury) is forced to penetrate the pores of the structure. The volume of mercury intruded into the pores can be measured directly as a function of the applied pressure $(\mathrm{P})$ using the Washburn equation:

$$
\mathrm{D}=-4 \gamma \mathrm{P}^{-1} \cos (\phi)
$$

where, $\mathrm{D}$ is the pore diameter $(\mu \mathrm{m}), \mathrm{P}$ is the applied pressure $(\mathrm{Pa}), \gamma$ is the surface tension of mercury $\left(\mathrm{mN} \cdot \mathrm{m}^{-}\right.$ $\left.{ }^{1}\right)$, and $\phi$ is the contact angle $\left(130^{\circ}\right)$ between the mercury and the sample. Varying the pressure level applied, the pore size distribution can be determined.

X-ray diffraction (XRD-6000, Shimadzu; CuK $\alpha$ radiation $=1.54439 \AA$ ) was performed in crushed samples $\left(D_{\text {Part }}<100 \mu \mathrm{m}\right)$ to indentify the phases formed and the microstructure at the external surface of the sintered samples was investigated by means of scanning electron microscopy (SEM, EVO MA10, Zeiss, previously covered by thin gold coating).

\section{RESULTS AND DISCUSSION}

In situ reactions in the $\mathrm{CaO}-\mathrm{Al}_{2} \mathrm{O}_{3}$ system have been extensively studied due to its importance in the production of calcium aluminate cement (CAC). These studies revealed that, depending on the reacting condition (particle size, degree of mixing, average distance amongst particles, mineraliser additives, timetemperature, and cooling rate), several intermediate compounds (such as $\mathrm{C}_{12} \mathrm{~A}_{7}$ ) with different composition can be formed before the $\mathrm{CA}_{6}$ stoichiometry is reached. In the present work, all sintered samples presented a XRD pattern similar to the pre-formed commercial electrofused $\mathrm{CA}_{6}$ grade, formed by a single and highly crystalline phase (Figure 2). These results indicate that the conditions employed favored the full conversion of the $\mathrm{Al}$ and $\mathrm{Ca}$ sources into $\mathrm{CA}_{6}$. 


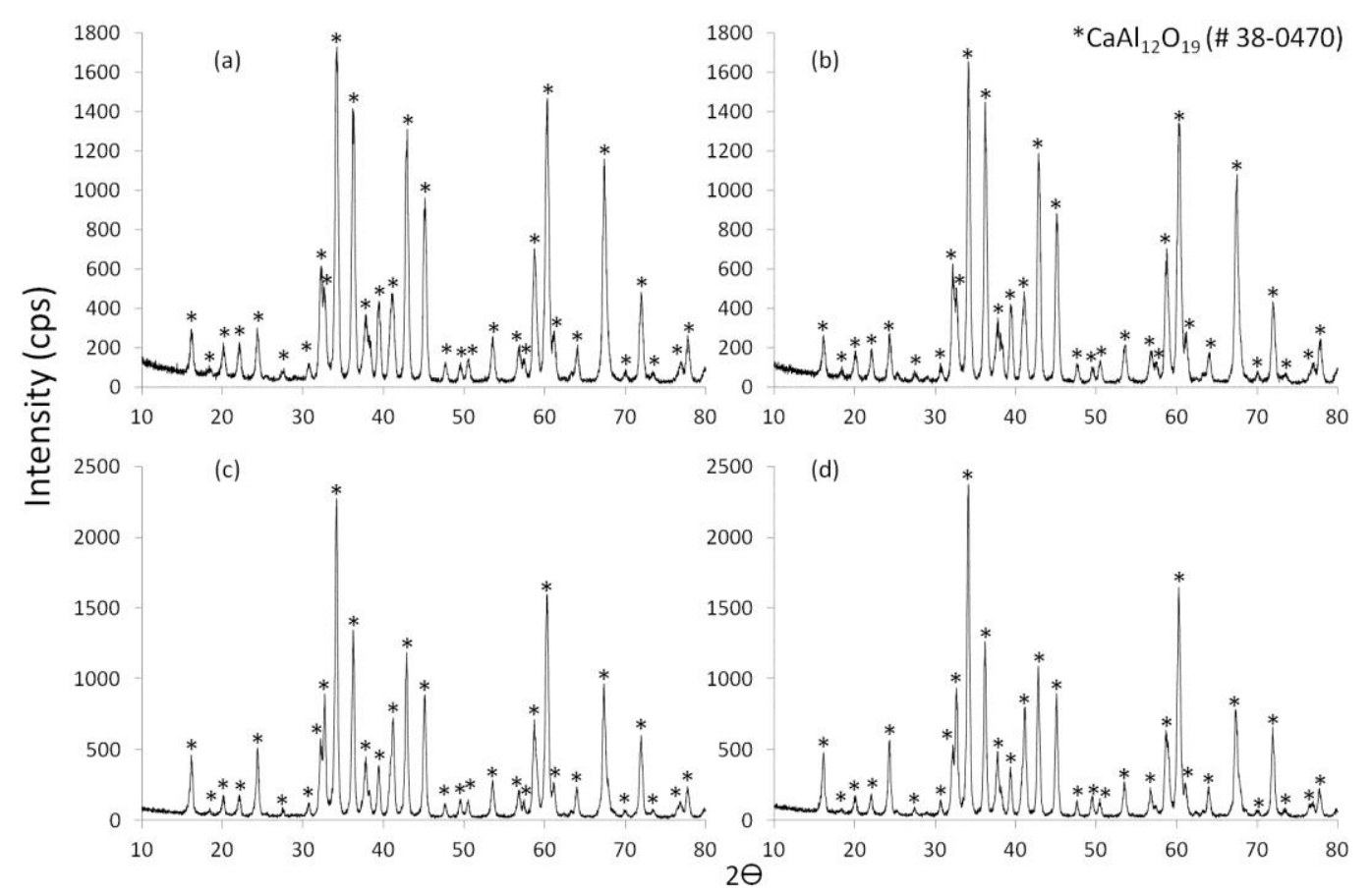

Figure 2: DRX patter for sample prepared by mixing (a) $\mathrm{CA}_{-} \mathrm{CaCO}_{3}(85.9: 14.1)$, (b) $\mathrm{CA}-\mathrm{Ca}(\mathrm{OH})_{2}(89.0: 11.0)$ sintered at $1600{ }^{\circ} \mathrm{C}$, and (c) $\mathrm{HA}-\mathrm{CaCO}_{3}(88.0: 12.0)$, (d) $\mathrm{HA}-\mathrm{Ca}(\mathrm{OH})_{2}(90.5: 9.5)$ sintered at $1650{ }^{\circ} \mathrm{C}(*=\mathrm{JCPDS}$ file $38-0470)$

Different apparent porosity levels (Figure 3) and average pore size (AVP, Figure 4) were achieved after thermal treatment depending on samples' composition and sintering temperatures.

The greatest porosity levels and AVP were achieved for the HA-containing samples sintered at $1550^{\circ} \mathrm{C}$. For the same $\mathrm{Al}_{2} \mathrm{O}_{3}$ source ( $\mathrm{CA}$ or $\mathrm{HA}$ ), samples with previously formed $\mathrm{CaO}$ (calcined $\mathrm{CaCO}_{3}$ ) presented porosity levels slightly higher. Despite the distinct composition, because this variation in porosity is smaller than 10 percent points, it can be attributed mainly to effects related to packing efficiency at the green state. Greater differences were observed between the different $\mathrm{Al}_{2} \mathrm{O}_{3}$ sources: HA containing samples presented porosity levels and AVP almost twice as high as the equivalent CA containing ones.

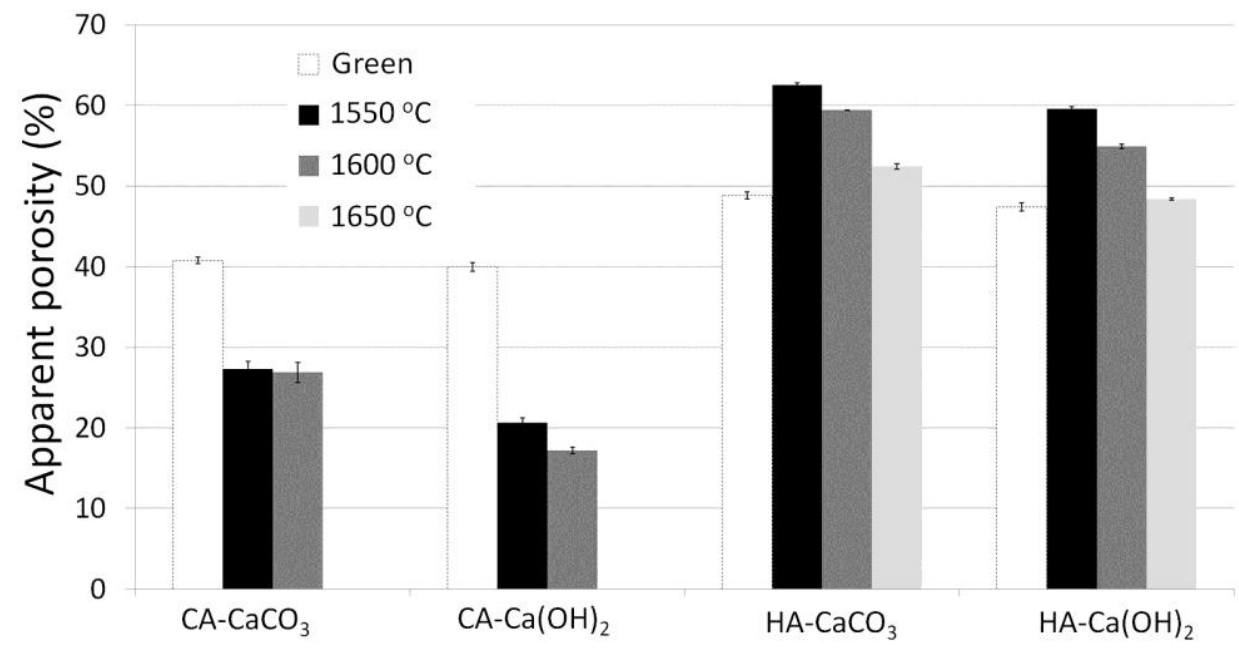

Figure 3: Apparent porosity for samples green and sintered at different temperatures. 


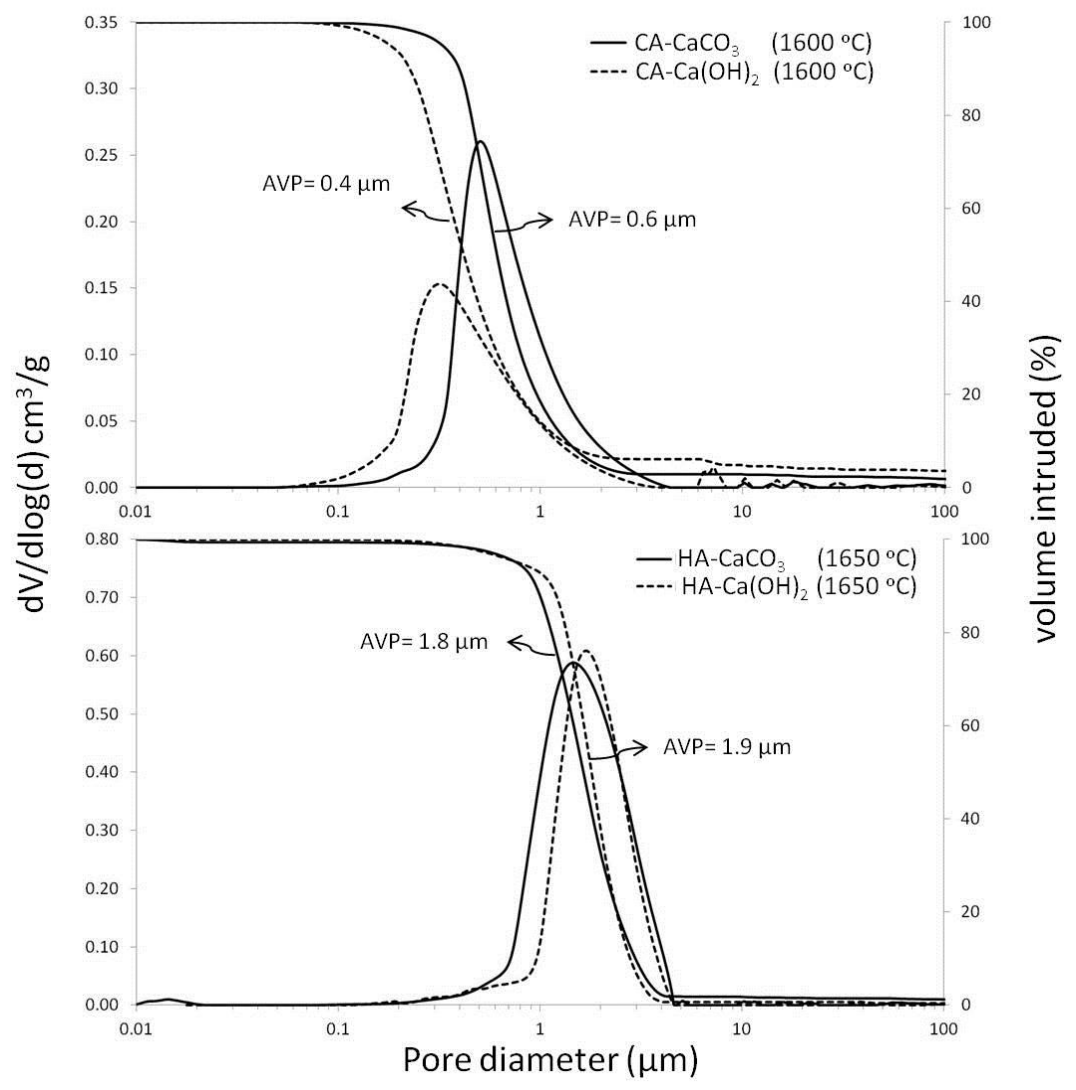

Figure 4: Pore size distribution for samples $\mathrm{CA}-\mathrm{CaCO}_{3}(85.9: 14.1), \mathrm{CA}-\mathrm{Ca}(\mathrm{OH})_{2}(89.0: 11.0)$ sintered at $1600{ }^{\circ} \mathrm{C}$, and $\mathrm{HA}-\mathrm{CaCO}_{3}(88.0: 12.0)$, (d) $\mathrm{HA}-\mathrm{Ca}(\mathrm{OH})_{2}(90.5: 9.5)$ sintered at $1650{ }^{\circ} \mathrm{C}$.

Since alumina sources are the major component of the compositions, it is reasonable to consider that these results can be attributed to the physicochemical differences between them. Firstly, because hydratable alumina presents larger average particle size and specific surface area compared to the calcined alumina (Table 1), its packing efficiency is significantly lower which generates high porosity at the green samples (Figure 3). Secondly, whereas calcined alumina is a highly stable compound (formed entirely by the $\alpha-\mathrm{Al}_{2} \mathrm{O}_{3}$ phase), hydratable alumina is comprised by $\rho-\mathrm{Al}_{2} \mathrm{O}_{3}$ phase that typically contains $10-15 \mathrm{wt} \%$ of chemically bonded water. At temperatures above $250^{\circ} \mathrm{C}, \rho-\mathrm{Al}_{2} \mathrm{O}_{3}$ turns into boehmite and, at higher temperatures, into other transition phases of alumina. During this process, the significant density increase (from 2.8 g.cm ${ }^{-3}$ up to $3.5 \mathrm{~g} . \mathrm{cm}^{-3}$ ) behaves as porogenic mechanism, also reported elsewhere [11]. The combination of these effects causes the enhancement of the average space amongst the $\mathrm{HA}$ and $\mathrm{CaO}$ particles, comparing to the $\mathrm{CA}$ and $\mathrm{CaO}$ ones.

Because $\mathrm{CA}_{6}$ formation is a solid-state diffusion-based reaction, during the first stages of sintering, particles densification is hindered. Besides this, since this reaction occurs mainly at contact points amongst the particles, the average size ratio between the alumina and calcia sources plays an important role. When coarse alumina particles (such as HA) are surrounded by thin calcia ones, at temperatures around $1400^{\circ} \mathrm{C}$, calcium alumina (CA) is preferentially formed at the contact points, generating a small portion of liquid phase. As the sintering process carries on, this liquid dissolves more alumina from the neighboring particles precipitating other alumina rich compounds: $\mathrm{CA}_{2}$ initially and $\mathrm{CA}_{6}$ latter. Probably due to the large amount of liquid phase formed on the contact region, these crystals tend to be thicker and more regular. For a combination of thin particles $\left(\mathrm{CA}\right.$ plus $\left.\mathrm{CaCO}_{3}\right)$, on the other hand, due to the larger number of contact points, the reaction occurs more likely as a solid-state diffusion, with low generation of liquid phases. Due to this, the atomic interdifusion occurs mainly at few high energy crystallographic planes, generating more asymmetrical crystals that growth until impinge upon each other. This mechanism is schematically shown on Figure 5.

The development of $\mathrm{CA}_{6}$ grains with different morphology can be explained in terms of distinct $\mathrm{CA}_{6}$ reaction mechanisms, resulting from differences in the reactivity of the powders [12]. In this work, samples $\mathrm{CA}-\mathrm{CaCO}_{3}$ presented a platelet structure, whereas for the $\mathrm{HA}-\mathrm{CaCO}_{3}$ ones, a more equiaxial morphology was observed, as showing at Figure 6. 

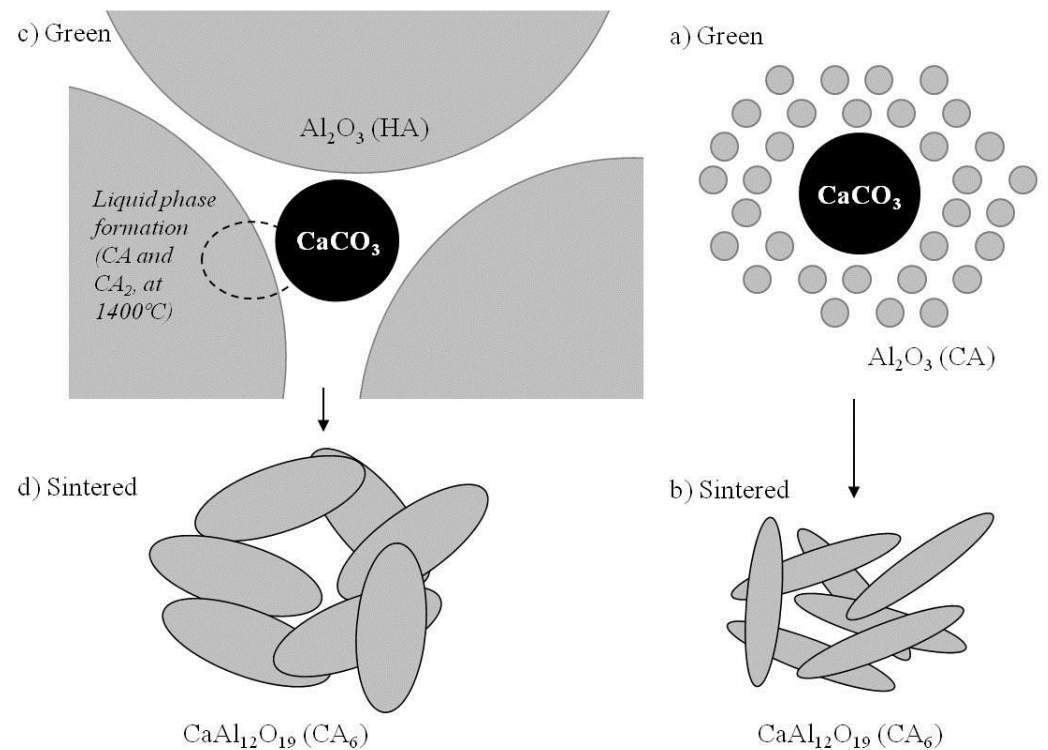

Figure 5: Schematic illustration of the reaction between the alumina and calcia sources for samples: (a, b) CA$\mathrm{CaCO}_{3}$ and (c, d) $\mathrm{HA}-\mathrm{CaCO}_{3}$ green and sintered at different temperatures.

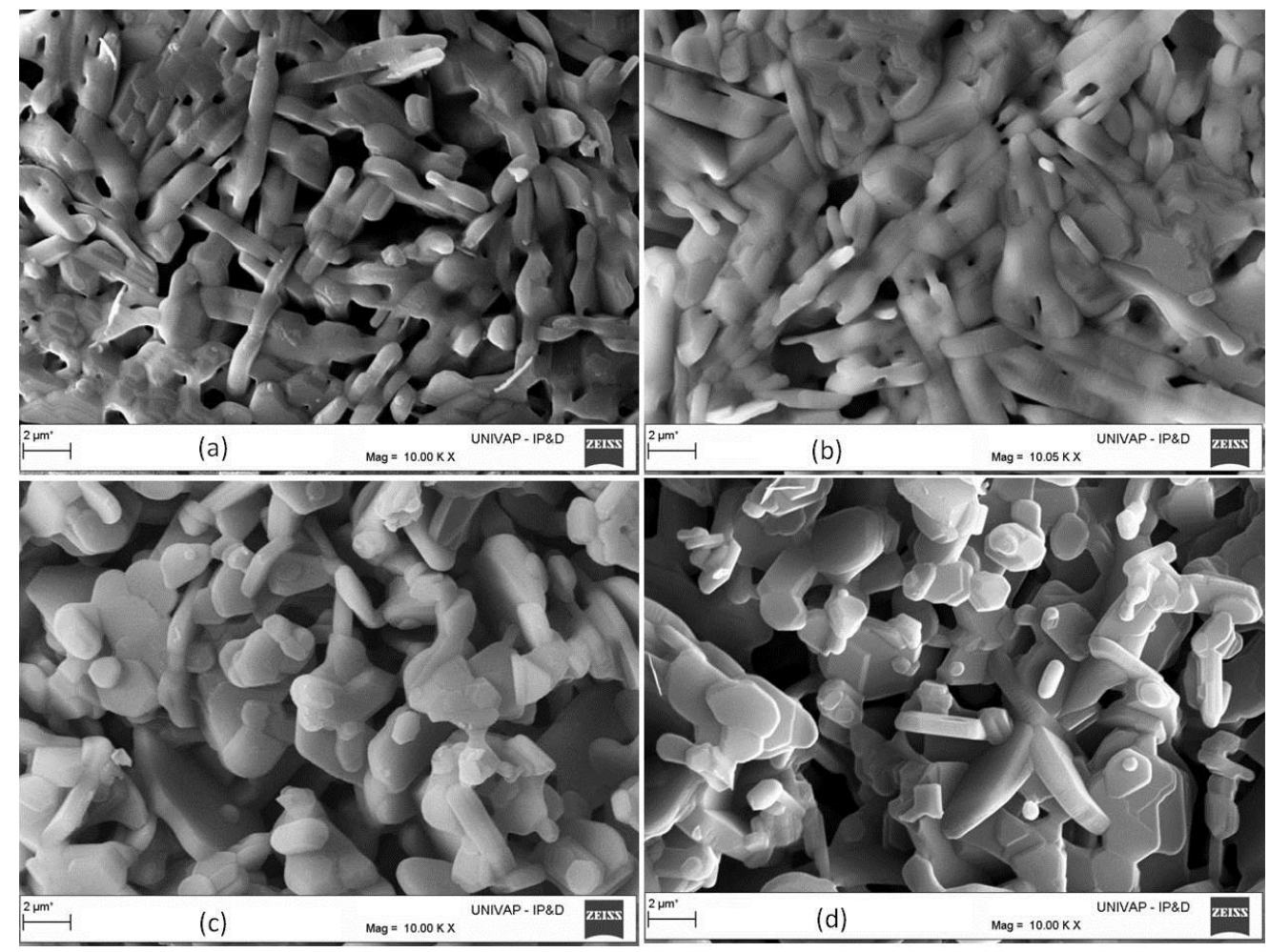

Figure 6: Scanning electron microscopy for samples (a) $\mathrm{CA}_{-} \mathrm{CaCO}_{3}(85.9: 14.1)$, (b) $\mathrm{CA}-\mathrm{Ca}(\mathrm{OH})_{2}(89.0: 11.0)$ sintered at $1600{ }^{\circ} \mathrm{C}$, and (c) $\mathrm{HA}-\mathrm{CaCO}_{3}(88.0: 12.0)$, (d) $\mathrm{HA}-\mathrm{Ca}(\mathrm{OH})_{2}(90.5: 9.5)$ sintered at $1650{ }^{\circ} \mathrm{C}$.

\section{CONCLUSIONS}

Mixtures of different sources of $\mathrm{Al}_{2} \mathrm{O}_{3}$ and $\mathrm{CaO}\left(\mathrm{CA}-\mathrm{CaCO}_{3}, \mathrm{CA}-\mathrm{Ca}(\mathrm{OH})_{2}, \mathrm{HA}-\mathrm{CaCO}_{3}, \mathrm{HA}-\mathrm{Ca}(\mathrm{OH})_{2}\right)$ were used for synthesize porous $\mathrm{CA}_{6}$ structures with a wide range of porosity and pore size distribution. High levels of porosity $(\sim 60 \%)$ and small average pore size $(1 \mu \mathrm{m})$ were obtained even for samples sintered at the highest sintering temperatures $\left(1600\right.$ and $\left.1650^{\circ} \mathrm{C}\right)$. The microstructures attained were strongly affected by the precursor raw materials. The grain morphology depends of calcium and alumina distributions in green spec- 
imens as well as their characteristics (average particle size and surface area). Reactions between CA and calcium sources result in platelet grains, while HA result in grains with curved boundaries and higher porosity. Finally, it was demonstrated that $\mathrm{Ca}(\mathrm{OH})_{2}$ is a suitable $\mathrm{CO}_{2}$-free alternative for replacing $\mathrm{CaCO}_{3}($ or $\mathrm{CaO}$ produced from $\mathrm{CaCO}_{3}$ ) in $\mathrm{CA}_{6}$ synthesis.

\section{ACKNOWLEDGMENTS}

The authors are grateful for grant \#2013/22502-8 from the São Paulo Research Foundation (FAPESP) and National Council for Scientific and Technological Development - Brazil (CNPq) for providing financial support for this research.

\section{BIBLIOGRAPHY}

[1] GARSEL, D. V., GNAUCK,V., KRIECHBAUM, G. W., et al., "New insulating raw material for high temperature applications", In: Proceedings of 41 International Colloquium on Refractories, pp. 122-128, Aachen, 1998.

[2] GARSEL, D. V., BUHR, A., GNAUCK, V., "Long term high temperature stability of microporous calcium hexaluminate based insulating materials", In: Proceedings of 42 International Colloquium on Refractories, pp. 181-186, Berlin, 1999.

[3] LORENZ, R. K., BUHR, A., RACHER, R. P., "Industrial application experiences with microporous calcium hexaluminate insulating material SLA-92", In: Proceedings of 48 International Colloquium on Refractories, pp. 66-70, 2005.

[4] OVERHOFF, A., BUHR, A., "New microporous materials for use in modern firing plants, cfi/Ber", $D K G$, v. 82, n. 8, pp. E1- E5, 2005.

[5] WIT, T., LORENZ, W., PORZGEN, D., et al., "Innovative ceramic fiber free steel ladle preheaters at Corus Steelworks IJ muiden”, In: Proceedings of 44 International Colloquium on Refractories, pp. 108-112, Aachen, 2001.

[6] DOMINGUEZ, C., CHEVALIER, J., TORRECILLAS, R., et al., "Microstructure development in calcium hexaluminate", Journal of the European Ceramic Society, v. 21, pp. 381-387, 2001.

[7] SCHNABEL, M., BUHR, A., CHEL, G. B., et al., "Advantages of calcium hexaluminate in a corrosive environment”, Refractories WorldForum, v. 3, n. 4, pp. 87-94, 2011.

[8] NAGAOKA, T., TSUGOSHI, T., HOTTA, Y., et al., "Forming and sintering of porous calciumhexaluminate ceramics with hydraulic alumina”, Journal Material Science, v. 41, pp. 7401-7405, 2006.

[9] AMTHAUER, K., BUHR, A., SCHNABEL, M., et al., "New european sinter aggregate with 96\% $\mathrm{Al}_{2} \mathrm{O}_{3}$ ", In: Proceedings of 54th International Colloquium on Refractories - Refractories for Industrials, pp. 95-98, Aachen, Germany, 2011.

[10] FRIDLAND, M., ROSADO, R., "Mineral trioxide aggregate (MTA) solubility and porosity with different water-to-powder ratios", Journal of Endodontics, v. 29, pp. 814-817, 2003.

[11] SOUZA, A. D. V., SOUSA, L. L., FERNANDES, L., et al., " $\mathrm{Al}_{2} \mathrm{O}_{3}-\mathrm{Al}(\mathrm{OH})_{3}-\mathrm{Based}$ castable porous structures", Journal of the European Ceramic Society, v. 35, n. 6, pp. 1943-1954, 2014.

[12] AN, L., CHAN, H. M., SONI, K. K., "Control of calcium hexaluminate grain morphology in in-situ toughened ceramic composites”, Journal of Materials Science, v. 31, n.12, pp. 3223-3229, 1996. 